\title{
FIRST DESCRIPTION OF BUCKLER CRAB CRYPTOPODIA ANGULATA (H. MILNE EDWARDS AND LUCAS 1841) FROM BANGLADESH MARINE WATER
}

\author{
S.M. Sharifuzzaman*, Sayedur Rahman Chowdhury, Md. Abu Sadek, \\ Md. Tariful Islam Fuad, C.M. Shahadat Hossain \\ Institute of Marine Sciences and Fisheries, University of Chittagong, \\ Chittagong-4331, Bangladesh
}

Two specimens of buckler crab were collected from the southeast coast of Bangladesh in August-September 2017. The crabs were examined morphologically and identified as Cryptopodia angulata (H. Milne Edwards and Lucas 1841), which is the only species of the genus Cryptopodia belonging to family Parthenopidae, occurring in the marine environment of Bangladesh.

The genus Cryptopodia (H. Milne Edwards 1834) is distributed in the IndoWest Pacific, Atlantic and Pacific coasts, and includes 13 species (Chiong and $\mathrm{Ng}$ 1998, Ng et al. 2008, WoRMS 2018a). These crabs have expanded margins of the carapace that completely hides the walking legs when they are folded (Chiong and Ng 1998), but no congener of Cryptopodia has been described from Bangladesh. Incidentally, Banu and Huda (1987) hinted the occurrence of $C$. angulata (H. Milne Edwards and Lucas 1841) at Chittagong coast in the early 1980s by referring to a manuscript in preparation (Banu and Huda 1987). Any published article in the subsequent years could not be traced out during our extensive literature survey; presumably it was never published. Those specimens of C. angulata were not even found in the museum of Department of Zoology at the University of Chittagong, where both the authors worked until retirement. But, literature suggests that Zoological Reference Collection (ZRC) of the Lee Kong Chian Natural History Museum (formerly Raffles Museum), National University of Singapore has the collection of Bangladesh specimen of C. angulata (Chiong and Ng 1998, Fatemi et al. 2012). However, to our knowledge, there is no published literature on the report of $C$. angulata from Bangladesh.

The buckler crabs were collected during cruises of 'RV Meen Sandhani', a survey and research vessel operated by the Department of Fisheries, Government of Bangladesh. Using shrimp trawl net, the crabs were caught from a location $63 \mathrm{~km}$ off the Inani coast of Cox’s Bazar district lying on $20.83683^{\circ} \mathrm{N}$, $91.56342^{\circ} \mathrm{E}$ at water depths of $67 \mathrm{~m}$ (Fig. 1). Environmental variables were not recorded, but past oceanographic records suggest that water temperature and

*Author for correspondence: <sharifuzzaman@cu.ac.bd>, < sharifuzzaman.imsf@gmail.com>

(C) 2018 Zoological Society of Bangladesh DOI: http://dx.doi.org/10.3329/bjz.v46i2.39058 
and salinity during the sampling time could be $28^{\circ} \mathrm{C}$ and $23.5 \mathrm{ppt}$ (Mahmood et al. 2002). The crabs were photographed, preserved in $10 \%$ formalin and transferred to $70 \%$ ethyl alcohol (ethanol) for long-term storage. Identification was carried out following the taxonomic key of Chiong and $\mathrm{Ng}$ (1998), and Naderloo (2017). The crabs were measured with a Vernier caliper to the nearest 0.1 millimetre $(\mathrm{mm})$. The voucher specimens have been kept as reference material in the museum of Institute of Marine Sciences and Fisheries at the University of Chittagong.

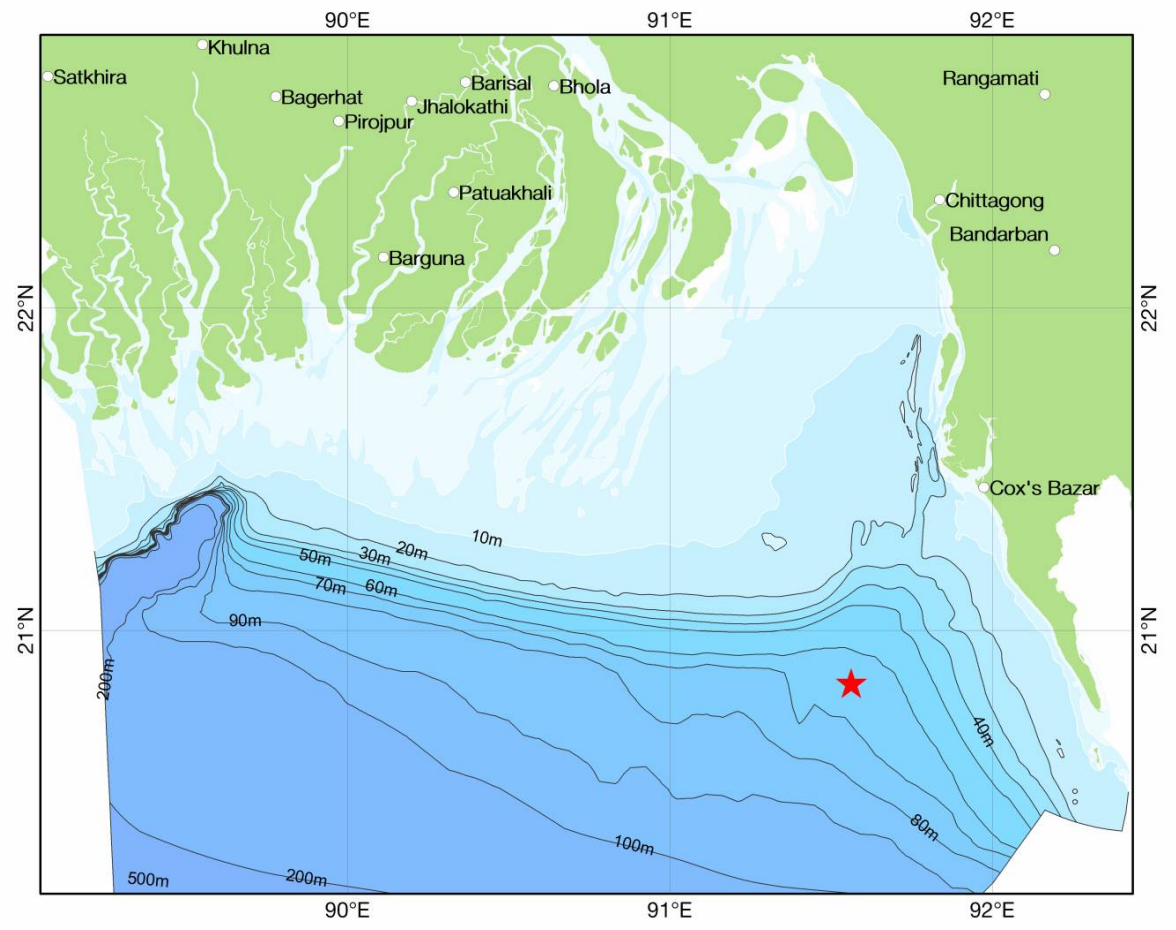

Fig. 1. Map showing the collection point (marked with a star) of Cryptopodia angulata in the northern Bay of Bengal, Bangladesh.

\section{Systematics:}

Order: Decapoda (Latreille 1806)

Family: Parthenopidae (MacLeay 1838)

Genus: Cryptopodia (H. Milne Edwards 1834)

Species: Cryptopodia angulata (H. Milne Edwards and Lucas 1841) (Fig. 2a, b, c)

Material examined: One male 32 by $56 \mathrm{~mm}$ (carapace length and width) and one female 30 by $52 \mathrm{~mm}$ (Table 1); $20.83683^{\circ} \mathrm{N}, 91.56342^{\circ} \mathrm{E}$, the coast of Cox's Bazar at southeast Bangladesh, August-September 2017. 
Description: The carapace is $~ 1.75$ times broader than long, convex in shape and sharply pentagonal with dentate edges, and carries curved spine at all angles. Two spines are present in the middle of the posterior margin of the carapace. The rostrum is triangular and ending in a sharp point. Lateral margins of carapace completely conceal the abdomen and the legs under it. The dorsal surface of carapace is granulated while ventral surface is smooth. A triangular depression is present in the middle of the carapace and the ridges bounding it are granular. Granules on the ridges begin from the apex of the triangular shape and end at the base of the rostrum on either side (Fig. 2a, b, c). The chelipeds are granular and robust. The palm contains denticles on anterior (four prominent teeth) and posterior margins. The carpus of chelipeds is semiglobular, the merus is flat and harbors wing-like expansions at the distal end. The legs are slender and smooth, and the first pair is considerably longer (Table 1). The surface of the third maxillipeds is smooth. Female abdomen is relatively narrow. Shell color is brown; live specimen is brown or pale pinkishbrown in colour.

Table 1. The morphometric data of Cryptopodia angulata

\begin{tabular}{lcc}
\hline \multirow{2}{*}{$\begin{array}{l}\text { Character } \\
\text { (length/width: mm; weight: g) }\end{array}$} & \multicolumn{2}{c}{ Cryptopodia angulata } \\
\cline { 2 - 3 } Carapace width & 56 & Female (†) \\
\hline Carapace length & 32.0 & 52 \\
Frontal width & 7.5 & 30.0 \\
Abdomen width & 13.4 & 7.3 \\
Abdomen length & 6.4 & 15.4 \\
Sternum width & 10.5 & 8.6 \\
Orbit length & 1.8 & 10.4 \\
Telson length & 3.2 & 1.8 \\
Chela length & 23.8 & 4.5 \\
Dactyl length & 10.0 & 23.6 \\
Merus length & 20.0 & 9.0 \\
1st walking leg length & 27.5 & 19.3 \\
2nd walking leg length & 26.6 & 21.2 \\
3rd walking leg length & 24.7 & 20.4 \\
4th walking leg length & - & 19.5 \\
Weight & 6.84 & 18.5 \\
No. of lateral spine on carapace & 8 & 5.00 \\
\hline
\end{tabular}

The global diversity of brachyuran crabs consists of 6800 species in 93 families (Ng et al. 2008) including 995 species from the Indian waters (Pillai and Thirumily 2008). In Bangladesh, there are 45 species of marine and estuarine 
crab belonging to families Calappidae, Carpiliidae, Daldorfiidae $(=$ family Parthenopidae; WoRMS 2018b), Dotillidae, Grapsidae, Leucosiidae, Majidae, Matutidae, Ocypodidae, Portunidae, Sesarmidae, Varunidae and Xanthidae (Johirul 1976, Shafi and Guddus 1982, Ng et al. 1987, Chowdhury and Hafizuddin 1991, Siddiqui and Zafar 2002, Ahmed et al. 2008, IUCN Bangladesh 2015, Akash and Chowdhury 2017, Akash and Hossain 2017). In particular, the family Parthenopidae consists of only one species, Daldorfia horrida (Ahmed et al. 2008, IUCN Bangladesh 2015). C. angulata of the family Parthenopidae is, therefore, a new addition to the list. The species prefers inhabiting sandy-muddy offshore marine environment (i.e. $63 \mathrm{~km}$ off the Cox's Bazar coast; Fig. 1) and appears to be uncommon in Bangladesh marine waters, as reported in other geographical context, i.e. Ravichandran et al. (2010). Recently, Silambarasan et al. (2015) has recorded the species from the southeast coast of India. The geographical distribution of C. angulata includes Australia, India, Indonesia, Malaysia, Maldives, Pakistan, Sri Lanka, Singapore and Thailand (Banu and Huda 1987, Chiong and Ng 1994, Ravichandran et al. 2010, Silambarasan et al. 2015).

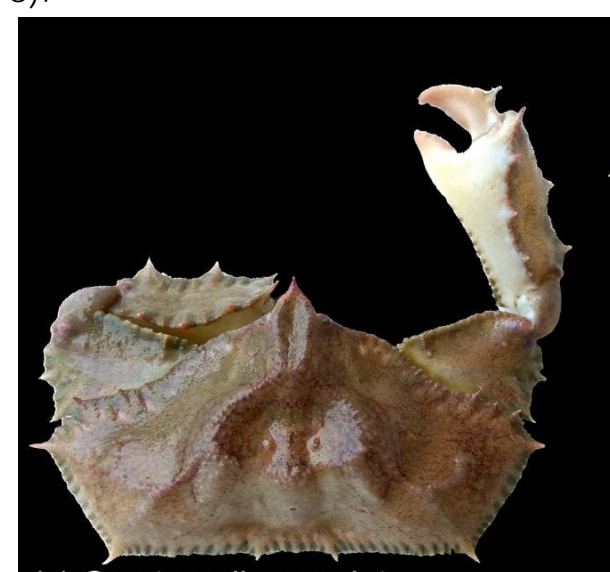

(a) Cryptopodia angulata

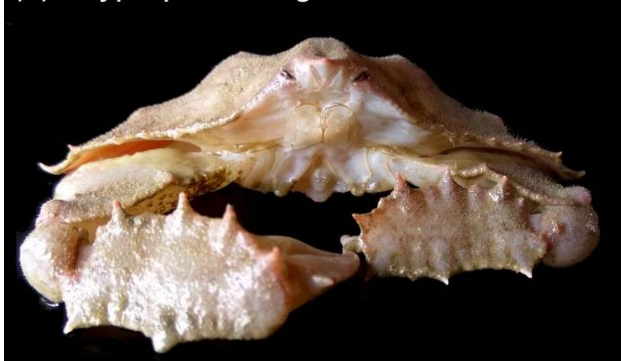

(c)

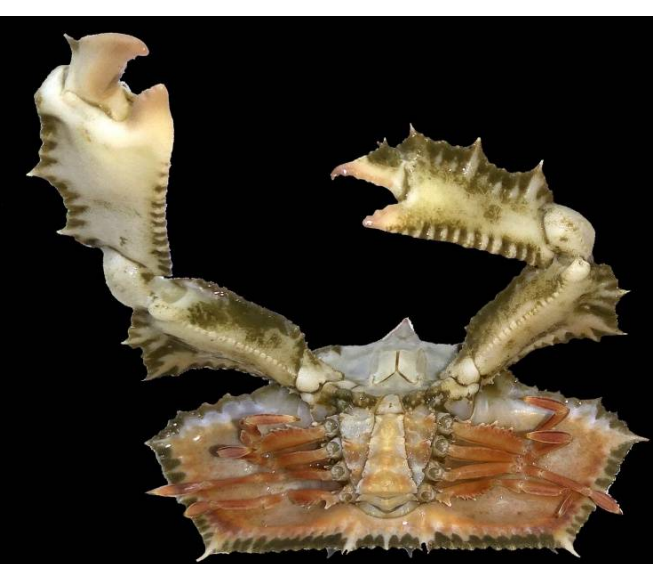

(b)

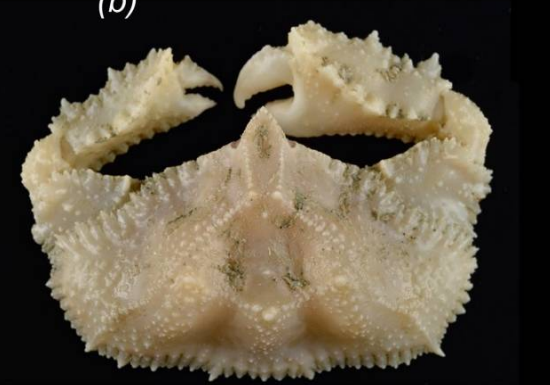

(d) Cryptopodia echinosa

Fig. 2. Cryptopodia angulata: (a) Dorsal view, (b) ventral view and (c) anterior view (this study); and (d) C. echinosa: dorsal view (source: Naderloo 2017) is given for comparison. 
The taxonomy of the buckler crabs of the genus Cryptopodia has been discussed in detail by Chiong and $\mathrm{Ng}$ (1998). Morphologically C. angulata shows a close resemblance to that of its congener C. echinosa (Chiong and $\mathrm{Ng}$ 1998), although they can be distinguished by certain characters. For example, i) shape of the carapace is more pentagonal in $C$. angulata vs. more triangular in $C$. echinosa, ii) granulation on the dorsal surface is less in C. angulata vs. more in C. echinosa (Fig. 2a, d), iii) the branchial region of the carapace are prominently more inflated in C. echinosa than in C. angulata, and iv) the median gastric depression is relatively deeper in C. echinosa than in C. angulata; as stated by Chiong and Ng (1998), Ravichandran et al. (2010), Fatemi et al. (2012), Silambarasan et al. (2015), and Naderloo (2017). However, C. echinosa is not known to occur in the coastal and marine waters of Bangladesh at northern Bay of Bengal.

The global range of distribution of $C$. angulata is not clearly documented. Therefore, knowledge on the distribution of any organism is not only important to understand the natural history but also to build up the baseline data for biodiversity conservation and management, especially for species like $C$. angulata that is observed only on an irregular basis.

Acknowledgements: The authors are thankful to the Department of Fisheries, Government of Bangladesh, for assisting with the collection of crab specimens.

\section{LITERATURE CITED}

AHMED, A.T.A., KABIR, S.M.H., AHMAD, M., RAHMAN, A.K.A., HAQUE, E.U., AHMED, Z.U., BEGUM, Z.N.T., HASSAN, M.A. and KHONDKER, M. (Eds). 2008. Encyclopedia of Flora and Fauna of Bangladesh, Vol. 18, Part II. Arthropoda: Crustacea. Asiatic Society of Bangladesh, Dhaka.

AKASH, M. and CHOWDHURY, G.W. 2017. First record of the Bengal fiddler crab Uca (Austruca) bengali Crane, 1975 (Brachyura: Ocypodidae) from Kuakata National Park, Bangladesh. Dhaka Univ. J. Biol. Sci. 26(2): 199-203.

AKASH, M. and HOSSAIN, M.A.R. 2017. First record of the two-striped box crab Calappa bilineata Ng, Lai \& Aungtonya, 2002 (Brachyura: Calappidae) from St. Martin's Island, Bangladesh. J. Threat. Taxa 9(1): 9771-9773.

BANU, Q. and HUDA, K.M.N. 1987. New record of Cryptopodia angulata Milne-Edwards \& Lucas (Parthenopidae: Decapoda: Crustacea) from Malaysian waters. J. Bombay Nat. Hist. Soc. 85: 646-647.

CHIONG, W.L. and NG, P.K.L. 1998. A revision of the buckler crabs of the genus Cryptopodia H. Miline Edwards, 1834 (Crustacea: Decapoda: Brachyura: Parthenopidae). Raffles Bull. Zool. 46(1): 157-216.

CHOWDHURY, S.H. and HAFIZUDDIN, A.K.M. 1991. Crab fauna of Bangladesh. Part 1. Some marine crabs from the Bay of Bengal. Chittagong Univ. Stud. Part II: Science 15(2): 65-77. 
FATEMI, S.M.R., VALINASAB, T., NG, P.K.L. and GHOTBEDDIN, N. 2012. First record of Cryptopodia echinosa (Crustacea: Decapoda: Brachyura: Parthenopidae) from Oman Sea. Mar. Biodiv. Rec. 5(e52): 1-3.

IUCN BANGLADESH. 2015. Red List of Bangladesh, Volume 6: Crustaceans. International Union for Conservation of Nature (IUCN), Bangladesh Country Office, Dhaka.

JOHIRUL, I. 1976. Brachyura of the Karnaphuli estuary and northeast part of the Bay of Bengal with a special reference to the biology of Scylla serrata (Forskål 1775) (Crustacea: Decapoda). M. Sc.Thesis, Department of Marine Biology, University of Chittagong. p. 160.

MAHMOOD, N., CHOWDHURY, S.R., SHARIF, A.S.M., UDDIN, M.M., ULLAH, M.S. and ISLAM, M.H. 2002. A review of research works on water quality of the lotic, estuarine and marine environment in Bangladesh. Institute of Marine Sciences, University of Chittagong, Chittagong.

NADERLOO, R. 2017. Family Parthenopidae MacLeay, 1938 (Elbow Crabs), pp. 161-168. In: Atlas of crabs of the Persian Gulf. Springer.

NG, P.K.L., HUDA, K.M.N. and BANU Q. 1987. Description of a new species of Demania Laurie, 1906 (Crustacea, Decapoda, Brachyura, Xanthidae) from the Bay of Bengal, Indian Ocean. J. Nat. Hist. 21 (4): 987-993.

NG, P.K.L., GUINOT, D. and DAVIE, P. 2008. Systema brachyuorum: part I. An annotated checklist of extant brachyuran crabs of the World. Raffles Bull. Zool. (suppl.) 17: 1-286.

PILLAI, S.L. and THIRUMILU, P. 2008. New record of brachyuran crabs from the Chennai coast. J. Mar. Biol. Assoc. India 50(2): 238-240.

RAVICHANDRAN, S., ANBUCHEZHIAN, R., SIVASUBRAMANIYAN, K. and RAMESHKUMAR, G. 2010. Expansion of occurrence of two bat crabs (Crustacea: Decapoda: Brachyura: Parthenopidae) from the west to southeast coast of India. Biotemas 23: 163-167.

SHAFI, M. and QUDDUS, M.M.A. 1982. Brachyura fauna of Bangladesh, p 369-396. In: Bangladesher Matsho Sampad (Fisheries Resources of Bangladesh, in Bengali). Bangla Academy, Dhaka.

SIDDIQUI, M.Z.H. and ZAFAR, M. 2002. Crabs in the Chakaria Sundarban area of Bangladesh. J. NOAMI 19(2): 61-77.

SILAMBARASAN, K., SUNDARAMANICKAM, A., SUJATHA, K. and SENTHILKUMAAR, P. 2015. First record of buckler crab Cryptopodia angulata (Decapoda: Brachyura: Parthenopidae) from Chennai coast (Bay of Bengal), India. J. Asia Pac. Biodiv. 8: 102-104.

WoRMS. 2018a. Cryptopodia H. Milne Edwards, 1834. Accessed through World Register of Marine Species at http://www.marinespecies.org/aphia.php?p=taxdetails\&id=439562 on 16-05-2018.

WoRMS. 2018b. Daldorfiidae Ng and Rodríguez, 1986. Accessed through World Register of Marine Species at: http://www.marinespecies.org/aphia.php?p=taxdetails\&id=877493 on 18-07-2018.

(Manuscript received on 22 July. 2018; revised on23 November, 2018) 